\title{
ALUMINUM AS A RISK FACTOR FOR ALZHEIMER'S DISEASE
}

\author{
Pricilla Costa Ferreira ${ }^{1}$ \\ Kamila de Almeida Piai ${ }^{1}$ \\ Angela Maria Magosso Takayanagui \\ Susana Inés Segura-Muñoz ${ }^{3}$
}

Ferreira PC, Piai KA, Takayanagui AMM, Segura-Muñoz SI. Aluminum as a risk factor for Alzheimer's disease. Rev Latino-am Enfermagem 2008 janeiro-fevereiro; 16(1):151-7.

The purpose of the study was to condense existing scientific evidence about the relation between aluminum $(A I)$ exposure and risk for the development of Alzheimer's Disease (AD), evaluating its long-term effects on the population's health. A systematic literature review was carried out in two databases, MEDLINE and LILACS, between 1990 and 2005, using the uniterms: "Aluminum exposure and Alzheimer Disease" and "Aluminum and risk for Alzheimer Disease". After application of the Relevance Test, 34 studies were selected, among which 68\% established a relation between $A$ l and $A D, 23.5 \%$ were inconclusive and $8.5 \%$ did not establish a relation between $A l$ and $A D$. Results showed that $A$ is associated to several neurophysiologic processes that are responsible for the characteristic degeneration of $A D$. In spite of existing polemics all over the world about the role of $A l$ as a risk factor for $A D$, in recent years, scientific evidence has demonstrated that $A l$ is associated with the development of $A D$.

DESCRIPTORS: Alzheimer disease; aluminum; risk factors

\section{ALUMINIO COMO FACTOR DE RIESGO PARA LA ENFERMEDAD DE ALZHEIMER}

El objetivo del estudio fue condensar la evidencia científica existente entre la exposición al aluminio (AI) y el riesgo para el desarrollo de la Enfermedad de Alzheimer (EA), evaluando los efectos para la salud de la población a largo plazo. Una revisión sistemática de la literatura científica existente entre 1990 y 2005 , fue realizada en dos bases de datos, MEDLINE y LILACS, utilizando los unitermos: "Aluminium exposure and Alzheimer Disease" y "Aluminium and risk for Alzheimer Disease". Fueron seleccionados 34 trabajos para la investigación, de los cuales $68 \%$ establecieron relação entre el Al y la EA, 23,5\% no presentaron datos conclusivos y 8,5\% no establecieron ninguna relación entre el Al y la EA. A partir de los resultados obtenidos, se verifica que el Al interviene en diversos procesos neurofisiológicos responsables por la degeneración característica de la EA. A pesar de la polémica existente en el médio científico, la evidencia científica demuestra a lo largo de los últimos años que el Al es uno de los determinantes para el desenvolvimiento de la EA.

DESCRIPTORES: enfermedad de Alzheimer; alumínio; factores de riesgo

\section{ALUMÍNIO COMO FATOR DE RISCO PARA A DOENÇA DE ALZHEIMER}

O objetivo do estudo foi condensar a evidência científica existente entre a exposição ao alumínio (Al) e risco para o desenvolvimento da doença de Alzheimer (DA), avaliando os efeitos para saúde da população, a longo prazo. Realizou-se revisão sistemática de literatura produzida entre 1990 e 2005, conduzida em duas bases de dados, MEDLINE e LILACS, utilizando os unitermos: "Aluminium exposure and Alzheimer Disease" e "Aluminium and risk for Alzheimer Disease". Foram selecionados 34 trabalhos para a pesquisa, desses, 68\% estabeleceram relação entre o $A$ l e a DA, 23,5\% não apresentaram dados conclusivos e 8,5\% não estabeleceram nenhuma relação entre o Al e DA. A partir dos resultados obtidos, verifica-se que o Al intervém em diversos processos neurofisiológicos responsáveis pela degeneração característica da DA. Apesar da polêmica existente, a evidência científica demonstra, ao longo dos últimos anos, que o Al se associa com o desenvolvimento da DA.

DESCRITORES: doença de Alzheimer; alumínio; fatores de risco

${ }^{1}$ Undergraduate Nursing Student, e-mail: sininha83@yahoo.com.br; ${ }^{2}$ Ph.D., Associate Professor, e-mail: ammtakay@eerp.usp.br; ${ }^{3}$ Ph.D., Professor, email: susis@eerp.usp.br. University of São Paulo at Ribeirão Preto College of Nursing, WHO Collaborating Centre for Nursing Research Development, Brazil. 


\section{INTRODUCTION}

Aluminum ( $\mathrm{Al}$ ) is a common metal in the environment and one of the most abundant in the terrestrial crust. Al is liberated in the environment by natural processes of soil erosion, volcanic eruptions and anthropogenic actions. Bauxite is the most important source, containing $55 \%$ of Al oxide.

The larger portion of $\mathrm{Al}$ ingestion is provided through food in different ways: food contaminated by $\mathrm{Al}$, water, and industrialized food that contains Al as conservant and/or colorant.

Even though food is an important source of Al ingestion, it is water which presents a higher bioavailability to be absorbed by the intestine ${ }^{(1)}$. Al salts are largely used as coagulants to reduce organic matter, turbidness and microorganisms present during treatment of superficial water, which presents the largest quantity of particles in suspension. This use, although useful for water treatment in many cities, can increase the concentration of $\mathrm{Al}$ at the final point of consumption ${ }^{(2)}$

Some studies appoint the presence of $\mathrm{Al}$ in potable water and in food as one of the etiological agents of mental diseases. There is also a hypothesis that exposure to this element represents a risk for the development of Alzheimer's disease ${ }^{(1)}$.

In 1965, an intracerebral inoculation of Al phosphate in rabbits was reported. It resulted in neurofibrilar degeneration significantly similar to the neurofibrilar degeneration of Alzheimer's Disease (AD), which led to the assumption that there is a relation between $A$ l and AD. In 1973, the first article that evidenced increase in Al concentration in patients with $A D$ was published ${ }^{(3)}$.

$A D$ is a neurodegenerative disorder prevalent in the senile population. It is clinically characterized by the progressive loss of memory and other cognitive abilities and pathologically by severe neuronal loss, glial proliferation and amyloid plaques composed of $\beta$-amyloid protein $(A \beta)$ surrounded by degenerated nervous terminations and neurofibrilar tangles ${ }^{(4)}$. This pathology is diagnosed when other dementia causes are excluded, because only necropsy permits the establishment of a definitive AD diagnosis ${ }^{(5)}$.

$A D$ is probably the result of a multifactorial process in which genetic and environmental components are included. It is supposed that individual genetic characteristics modulate environmental exposures. Environmental risk factors related to the development of $A D$ include exposition to $A l$, one of the most studied potential environmental risk factors. $A D$ has also being related with other risk factors, such as the chemical risk related to the reduction of neurotransmitters, which would be responsible for intellectual and behavioral performance in brains of patients with $A D^{(6)}$.

Another risk factor is the Apolipoprotein E susceptibility gene, which is related to $A D^{(5)}$. Some researchers believe that alterations in aging neurons can lead to a self-immune answer, giving origin to $A D^{(6)}$.

There is also a hypothesis of association with alterations in the hematoencephalic barrier and with severe brain injury, which lead to a loss of conscience and eventual development of $A D^{(6)}$. Age and a family history of dementia appear as the most important risk factors in the disease etiology.

Considering that there is a natural loss of immune answer capacity during the aging process, the development of pathologies is most frequent and most severe in aged persons. In addition, there are extrinsic factors, life style, socioeconomic condition and psychosocial and environmental factors determining functional, cellular and molecular alterations, which lead to diminished homeostatic balance and, consequently, greater predisposition to diseases ${ }^{(7)}$.

Demographic and epidemiological data indicate population aging all over the world. It is estimated that the number of people affected by $A D$ in the world will surpass 26 million; in Brazil, estimates refer to around 500 thousand people. The disease prevalence ranges from $1.4 \%$ of individuals between 65 and 69 years old to $20.8 \%$ of those between 85 and 89 years old, reaching approximately $38.6 \%$ of those between 90 and 95 years old ${ }^{(7)}$. AD represents $70 \%$ of the set of diseases that affect the geriatric population.

This article condensed existing scientific evidence of the relation between $\mathrm{Al}$ exposure and the risk of development of $A D$ from research results published between 1990 and 2005, using a reproducible bibliographic review technique called Systematic Literature Review.

\section{METODOLOGY}

The systematic literature review was conducted according to a sequence of steps described in Figure 1. 


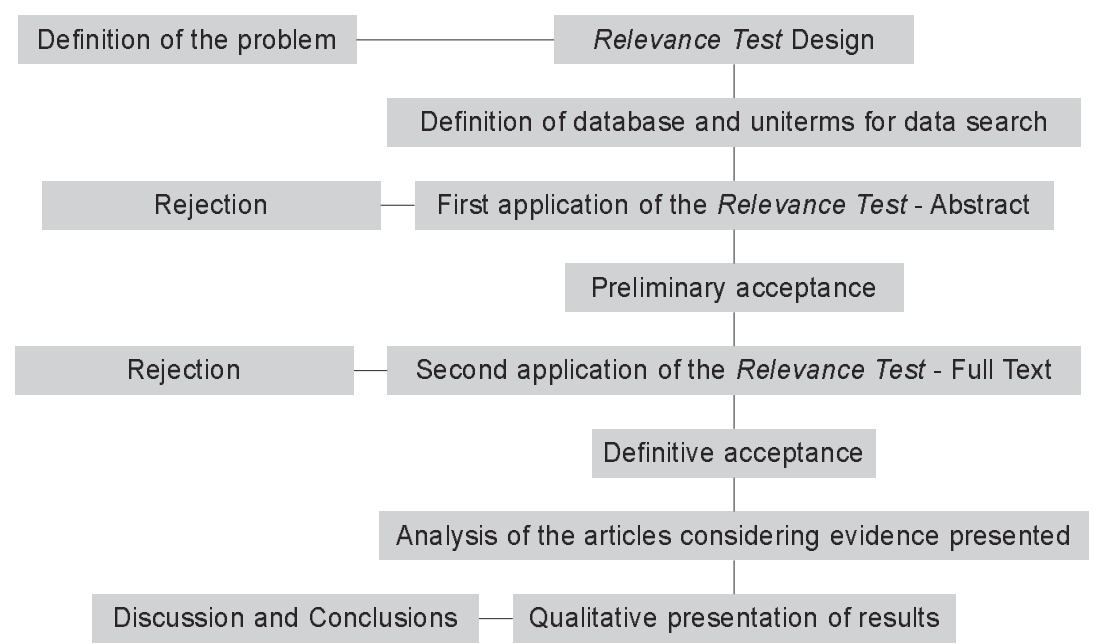

Figure 1 - Flow chart for the conduction of a Systematic Literature Review ${ }^{(8)}$.

The relation between exposure to $\mathrm{Al}$ and the risk of developing $A D$ was the focus of this study. The literature search was conducted in publications between 1990 and 2005, in two databases, MEDLINE and LILACS. The articles were identified through the uniterms: Aluminum Exposure and Alzheimer Disease, and Aluminum and Risk for Alzheimer Disease.

The criteria defined in the Relevance Test were used for the selection of studies. Only studies that positively answered all inclusion criteria participated in the Systematic Literature Review. These criteria are: a) Is the study about AD and/or Al toxicity? ; b) Does it address potential etiological agents or risk factors for development of AD?; c) Was it published between January 1990 and December 2005?; d) Was it published in English, Spanish, Portuguese or French?

The search in the databases and application of the Relevance Test, both to abstracts as to full texts, were carried out by two researchers independently, aiming to assure method objectivity. The Relevance Test was applied twice. It was first applied to the abstracts and, then, the articles that would participate preliminarily in the study were selected ${ }^{(8)}$. After that, all full articles were collected for the application of the second Relevance Test. After the study was completely read, its inclusion or exclusion in the study was confirmed. In view of divergences regarding the inclusion or exclusion of some studies, a third researcher was consulted, according to recommendations by the Cochrane Foundation. Bibliographic, editorial reviews, or communications were not included in the Systematic Literature Review.
Once the full texts had been selected, the information was analyzed and organized in synoptic charts, presenting the bibliographic reference. Thus, the existing experimental evidence on the relation between exposure to $\mathrm{Al}$ and the risk of developing $A D$ was condensed from the results of this study.

\section{RESULTS}

In this search, 174 studies related with the theme were obtained. After the application of the Relevance Test, 69 studies were selected and 16 were excluded because they included no abstracts, 40 did not affirmatively answer all questions of the Relevance Test, 43 were review articles and 6 were comments. From the 69 studies selected through the first application of the Relevance Test, 46 full texts were obtained.

The 46 full texts were reviewed and analyzed, aiming to identify the type of relation between $\mathrm{Al}$ and AD. After the second application of the Relevance Test, 34 studies were selected and 12 articles were excluded: two were comments, six did not affirmatively answer all questions of the Relevance Test and four were reviews. Of the 34 articles selected for the study, $68 \%$ (23 studies) established a relation between Al and AD, $23.5 \%$ (8 studies) did not present conclusive data and $8.5 \%$ (three studies) did not establish any relation between $\mathrm{Al}$ and AD. Table 1 shows studies that did not present conclusive data or did not establish a relation between $A l$ and $A D$ and Table 2 presents articles that established a relation between $\mathrm{Al}$ and $\mathrm{AD}$. 
Table 1 - Studies that did not present conclusive data or did not establish any relation between $A$ I and $A D$

\begin{tabular}{|c|c|}
\hline Author and Bibliographic Reference & Title \\
\hline Am J Clin Nutr 2005 april; 81(4):897-902. & $\begin{array}{l}\text { Cognitive impaiment and composition of drinking water in women: findings of the } \\
\text { EPIDOS Study. }\end{array}$ \\
\hline Polizzi et al. Neurotoxicology 2002 December; 23(6):761-74. & Neurotoxic effects of aluminium among foundry workers and Alzheimer's disease. \\
\hline Belles et al. Alzheimer Dis Assoc Disord 1998; 12(2):83-7. & $\begin{array}{l}\text { Silicon reduces aluminum accumulation in rats: relevance to the aluminum } \\
\text { hypothesis of Alzheimer disease. }\end{array}$ \\
\hline Mundy et al. Mol Chem Neuropathol 1997; 32(1-3):41-57. & $\begin{array}{l}\text { Aluminum potentiates glutamate-induced calcium accumulation and iron-induced } \\
\text { oxygen free radical formation in primary neuronal cultures. }\end{array}$ \\
\hline McLachlan et al. Neurology 1996 February, 46(2):401-5. & $\begin{array}{l}\text { Risk for neuropathologically confirmed Alzheimer's disease and residual aluminum } \\
\text { in municipal drinking water employing weighted residential histories. }\end{array}$ \\
\hline Forster et al. J Epidemiol Community Health 1995 June; 49(3):253-8. & $\begin{array}{l}\text { Risk factors in clinically diagnosed presenile dementia of the Alzheimer type: a } \\
\text { case-control study in northern England. }\end{array}$ \\
\hline Kuroda \& Kawahara. Gerontology 1995; 41(Suppl 1):2-6. & $\begin{array}{l}\text { Application of long-term cultured neurons in aging and neurological research: } \\
\text { aluminum neurotoxicity, synaptic degeneration and Alzheimer's disease. }\end{array}$ \\
\hline Domingo et al. Res Commun Chem Pathol Pharmacol 1993 March; 79(3):377-80. & $\begin{array}{l}\text { Effect of various dietary constituents on gastrointestinal absorption of aluminum } \\
\text { from drinking water and diet. }\end{array}$ \\
\hline Graves J. Clin Epidemiol 1990; 43(1):35-44. & The association between aluminum-containing products and Alzheimer's disease \\
\hline Graves et al. Occup Environ Med 1998 September; 55(9):627-33. & $\begin{array}{l}\text { Occupational exposures to solvents and aluminium and estimated risk of } \\
\text { Alzheimer's disease. }\end{array}$ \\
\hline Salib \& Hillier. Br J Psychiatry 1996 February, 168(2):244-9. & A case-control study of Alzheimer's disease and aluminium occupation. \\
\hline
\end{tabular}

Table 2 - Studies that presented a relation between exposure to Al and AD

Author and Bibliographic Reference

Matsuzaki et al. J. Neurochem 2004 March; 88(6):1345-51.

Dave et al. Brain Res Bull 2002 June; 58 (2):225-33.

Trippi et al. Mutagenesis 2001 July, 16(4):323-7.

Freitas et al. Cad. Saúde Pública 2001; 17(3):651-60.

Kawahara et al. Brain Res Bull 2001 May, 55(2):211-7.

Bosetti et al. Neuroreport 2001 March6; 12(4):721-4

Oshiro et al. Biochim Biophys Acta 2000 November 15; 1502(3):405-14.

Rondeau et al. Am J Epidemiol 2000 July, 152(1):59-66.

Tanino et al. Biochem Biophys Res Commun 2000 May, 271(3):620-5.

Campbell et al. Proc Soc Exp Biol Med 2000 April; 223(4):397-402.

Swegert. et al. Mech Ageing Dev 1999 December, 112(1):27-42.

Campbell et al. Free Radic Biol Med 1999 May, 26(9-10):1166-71.

Rogers \& Simon. Age Ageing 1999 Mar; 28(2):205-9.

Mjöberg et al. Acta Orthop Scand 1997 December, 68(6):511-4.

Paik et al. Arch Biochem Biophys 1997 Augost 15; 344(2):325-34.

Neiva et al. Braz J. méd. biol Res 1997; 30(5):599-604.

Tokutake et al. Neurosci Lett 1995 February, 185(2):99-102.

Yokel et al. Cell Mol Neurobiol 1994 December; 14(6):791-808.

Yokel et al. Cell Mol Neurobiol 1994 December; 14(6):791-808.

Yokel et al. Cell Mol Neurobiol 1994 December; 14(6):791-808.

Yokel et al. Cell Mol Neurobiol 1994 December; 14(6):791-808.

Yokel et al. Cell Mol Neurobiol 1994 December; 14(6):791-808.

\section{Title}

Metals accelerate production of the aberrant splicing isoform of the presenilin-2. Effect of long-term aluminum feeding on kinetics attributes of tissue cholinesterases. Spontaneous and induced chromosome damage in somatic cells of sporadic and familiar Alzheimer's disease patients.

The importance of the water analysis for the public health in two regions of Rio de Janeiro: a focus on fecal coliforms, nitrates and aluminum.

Effects of aluminum on the neurotoxicity of primary cultured neurons and on the aggregation of ß-amyloid protein.

Mitochondrial cytochrome c oxidase subunit III is selectively down-regulated by aluminum exposure in PC12S cells.

Glial cells contribute more to iron and aluminum accumulation but are more resistant to oxidative stress than neuronal cells.

Relation between aluminum concentrations in drinking water and Altheimer's disease: an 8-year follow-up study.

Increase in phospholipase C-d1 protein levels in aluminum-treated rat brains.

Aluminum increases levels of $ß$-amyloid and ubiquitin in neuroblastoma but not in glioma cells.

Effect of aluminium-induced Alzheimer like condition on oxidative energy metabolism in rat liver, brain and heart mitochondria.

Aluminum-induced oxidative events in cell lines: glioma are more responsive than neuroblastoma.

A preliminary study of dietary aluminium intake and risk of Altheimer's disease.

Aluminum, Altheimer's disease and bone fragility.

Aluminum-induced structural alterations of the precursor of the non-Aß component of Altheimer's disease amyloid.

Aluminium induces lipd peroxidation and aggregation of human blood platelets. Aluminium detected in senile plaques and neurofibrillary tangles is contained in lipofuscin granules with silicon, probably as aluminosilicate.

Studies of aluminum neurobehavioral toxicity in the intact mammal.- Estudo1- Al produces an age-dependent leaming defict.

Studies of aluminum neurobehavioral toxicity in the intact mammal - Estudo 4 Aluminum intoxication reduces hippocampal acetylcholine owerfloew.

Studies of aluminum neurobehavioral toxicity in the intact mammal - Estudo 5 - The Alinduce learning defcit is associated with attenuation of hippocampal acetylcholine overflow.

Studies of aluminum neurobehavioral toxicity in the intact mammal - Estudo 6 - The entry of $\mathrm{Al}$ into the brain is rapid and is a function of brain site, animal species, and $\mathrm{Al}$ form.

Studies of aluminum neurobehavioral toxicity in the intact mammal - Estudo 7- Steadystate Al brain-blood ratios are $<1$ for several Al forms, further suggesting active processes at the BBB affectin brain Al distribution.

Alzheimer's-disease-like changes in tau protein processing: association with aluminium accumulation in brains of renal dialysis patients. 


\section{DISCUSSION}

Despite the epidemiological, social, and economic importance of $A D$ in the world, this study evidenced that few studies have been published on this topic in Latin America. Almost all selected studies originated in Europe, the United States, Canada or Asia; only one of the selected studies is from Latin America, specifically from Brazil.

According to the Systematic Literature Review, $A D$ is associated with a general reduction of cerebral tissue, with localized loss of neurons, mainly in the hypofield and basal forebrain. An experimental study performed with mice treated with Al demonstrated a statistically significant reduction in their brain weight ${ }^{(9)}$. Two microscopic aspects are typical in $A D$, the extra cellular amyloid plaques, also called senile plaques, which consist of extra cellular deposits of $A \beta$ protein, and neurofibrilar intraneuron tangles that consist of filaments of a fosforilated form of a protein associated to microtubes (Tau). Alteration in the processing of the $A \beta$ protein from its precursor, APP (amyloid precursor protein), is recognized as an essential characteristic in the AD pathogeny ${ }^{(10)}$.

There are two types of $A \beta$ protein, $A \beta 40$ and the $A \beta 42$. The $A \beta 40$ protein is normally produced in small quantities, though the $A \beta 42$ presents a super production due genetic mutations. Both proteins aggregate to form amyloid plaques. However, the $A \beta 42$ presents a higher tendency to do this than $A \beta 40$, constituting the main responsible in the formation of amyloid plaques. The $A \beta 40$ and $A \beta 42$ are produced by proteolytic cleavage of a precursor amyloid protein, the APP, a protein of larger membrane and normally expressed by many cells, including neurons of the central nervous system ${ }^{(10)}$. The APP mutations of genes ease the formation of $A \beta$, especially the $A \beta-42$ (Figure 2), with consequent increase in the formation of amyloid plaques ${ }^{(10)}$. It has been observed that $\mathrm{Al}$ increases the $A \beta$ protein neurotoxicity, the degeneration of neurons exposed to it and also aggregation of $A \beta$ protein $^{(11)}$.

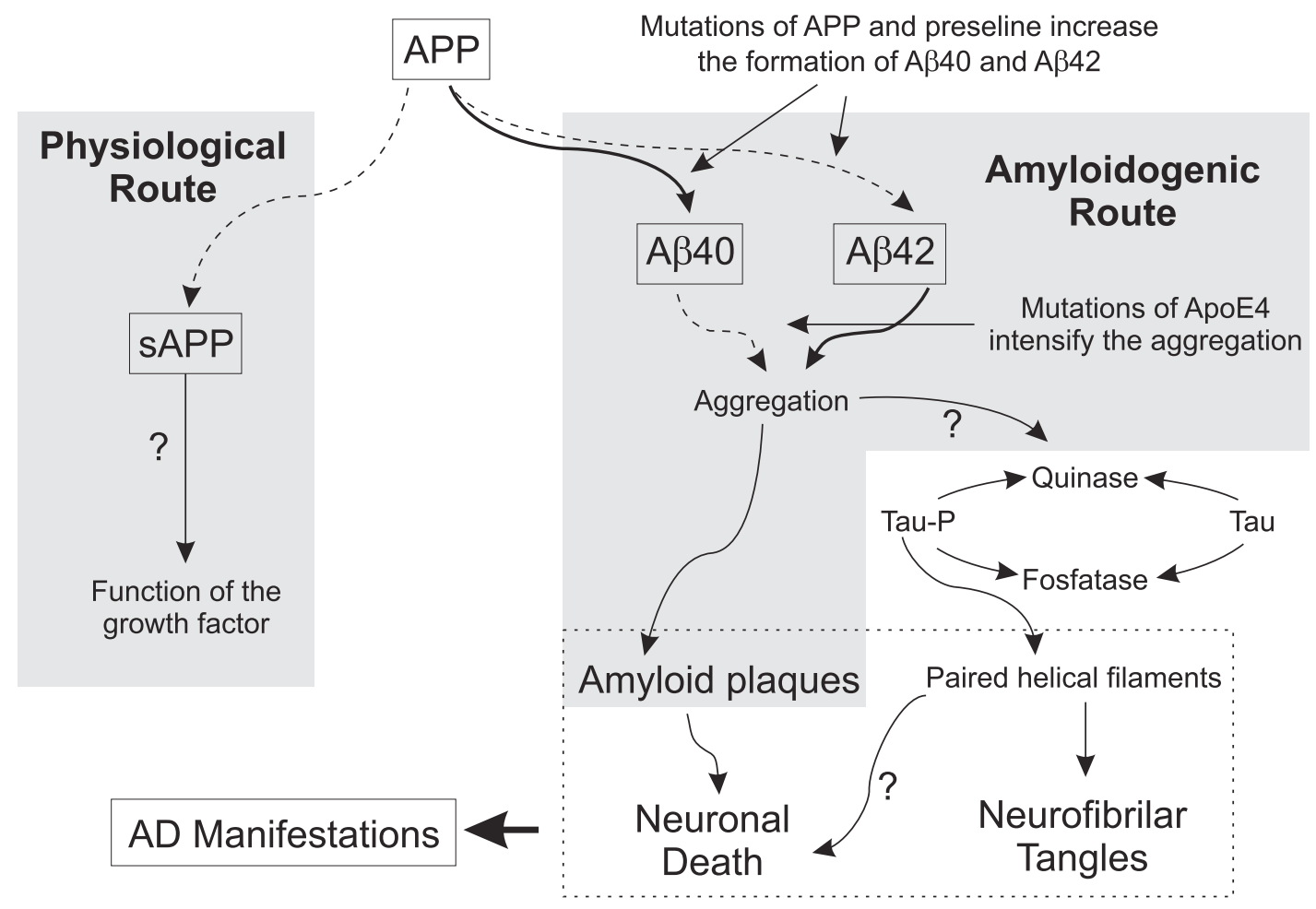

Figure 2 - Adapted diagram of APP processing. The physiological route originates the APP; mutation in the APP originates $A \beta$, aggregation is favored by mutation in the ApoE4 gene. Triggering of neurofibrilar tangles formation and processes of neuronal death; AD manifestations ${ }^{(10)}$.

Tau protein becomes abnormally fosforilated in $A D$ and is deposited intracellulary under the form of paired helical filaments with a characteristic microscopical aspect. When the cell dies, these filaments aggregate as neurofibrilar extracellular tangles. There is a strong influence of $\mathrm{Al}$ ions on fosforilation which can 
be the cause, because neurofibrilar tangles contain hyperfosfolated microtubules associated to the Tau protein. It is possible that the Tau fosforilation is intensified by the existence of myloid plaques. Its fosforilation compromises rapid axonal transport, a process that depends on the microtubule ${ }^{(10)}$.

The increased concentration of $\mathrm{Al}$ favors the formation of Tau protein and, consequently, the formation of neurofibilar tangles ${ }^{(12)}$. It was discovered in a previous study that the amyloid plaques are surrounded by glial reactive cells, Thus, exposition to Al can activate the oxidative processes of glial cells, which in turn can indirectly damage the neurons integrity ${ }^{(13)}$.

The neuron degeneration observed in $A D$ can also occur due to oxidative stress. Oxidative stress refers to conditions like as hypoxia, characterized by compromised protection mechanisms, as the neurons become more susceptible to excitotoxic lesion. Oxidative stress is induced in brains exposed to $\mathrm{Al}^{(10)}$.

It was demonstrated in an epidemiological study that individuals who used to ingest food with high Al contents presented a two times higher risk of developing $A D^{(14)}$.

Studies show that mice with prolonged exposure to $\mathrm{Al}$ soluble salt can develop $A D$, with selective loss of neurons and the cholinergic function. Al also diminishes the transmission of acetylcholine and attenuates its release, causing reduction of reflexes. Al appears as a reductor of neuronal activity, showing similarity with the decreased cholinergic action in AD. Al leads to behavioral alterations only in old rabbits, not in the young ones. Thus, mature brains are more susceptible to Al toxicity than immature ones ${ }^{(15)}$.

\section{FINAL CONSIDERATIONS}

Results show that $68 \%$ of the analyzed studies present $A l$ as one of the risk factors for $A D$, confirming and describing the toxicological mechanisms through which $\mathrm{Al}$ affects the nervous tissue.

In this study, the need to understand the importance of environmental factors is highlighted, especially exposure to $\mathrm{Al}$, as determinants in the population's health-disease process, stressing its potential to affect, positively or negatively, natural aging processes.

It was verified through a general evaluation of studies that, according to an important group of researchers, Al affects several neurophysiological processes, responsible for the degeneration characteristic of AD. Therefore, scientific evidence has shown that, in the last years, Al has been associated with the development of AD. Thus, preventing exposure to certain environmental factors like $\mathrm{Al}$, among others, could diminish the incidence of chronicdegenerating diseases like $A D$, which in recent years has acquired great importance for collective health all over the world.

\section{ACKNOWLEDGEMENTS}

This study was funded by CNPq through the concession of undergraduate scientific grant CNPq/ PIBIC (Process No 111339/2004-9) and CAPES ProDoc/CAPES Program (Process $N^{\circ}$ 00023/03-5).

\section{REFERENCES}

1. Martyn CN, Coggan D, Inskip H, Lacey RF, Young WF. Aluminum concentrations in drinking water and risk of Alzheimer's disease. Epidemiology 1997 May; 8(3):281-6. 2. Bates AJ. Water as consumed and its impact on the consumer-do we understand the variables? Food Chem Toxicol 2000; 38(1 Suppl):29-36.

3. Alfrey AC. Aluminium and renal disease. In: Bourke E, Mallick NP, Pollak VE. Moving points in nephrology. Contrib Nephrol 1993; 102:110-24.

4. Selkoe DJ. Normal and abnormal biology of the betaamyloide precursor protein. Annu Rev Neurosci 1994; 17:489-517

5. Yokel RA. The toxicology of aluminum in the brain: a review. Neurotoxicology 2000 Octuber; 21(5):813-28.

6. Associação Brasileira do Alumínio. Alumínio e saúde. $2^{a}$ ed. São Paulo (SP): ABAL; 2000.
7. Freitas EV, Py L, Neri AL, Cancado FAX, Gorzoni ML, Rocha SM. Tratrado de geriatria e gerontologia. Rio de Janeiro (RJ): Guanabara Koogan; 2002.

8. Segura-Muñoz SI, Takayanagui AMM, Lopes TM, Trevilato TMB, Hering SE. Estudo do efeito neurotóxico da exposição ocupacional ao manganês, mercúrio e chumbo utilizando como ferramenta metodológica a revisão sistemática de literatura. Mundo da Saúde 2003 outubro-dezembro; 27(4):589-95.

9. Tanino H, Shimohama S, Sasaki Y, Sumida Y, Fujimoto S. Increase in phospholipase $\mathrm{C}$-ä1 protein levels in aluminumtreated rat brains. Biochem Biophys Res Commun 2000 May; 271(3):620-5.

10. Hang HP, Dale MM, Ritter M. Farmacologia. $4^{a}$ ed. Rio de Janeiro (RJ): Guanabara Koogan; 2001.

11. Kawahara M, Midori K, Kuroda Y. Effects of aluminum on the neurotoxicity of primary cultured neurons and on the aggregation of $\beta$-amyloid protein. Brain Res Bull 2001 May; $55(2): 211-7$. 
12. Campbell A, Kumar A, La Rosa FG, Prasad KN, Bondy SC. Aluminum increases levels of beta-amyloid and ubiquitin in neuroblastoma but not in glioma cells. Proc Soc Exp Biol Med 2000 April; 223(4):397-402.

13. Campbell A, Prasad KN, Bondy SC. Aluminum-induced oxidative events in cell lines: Glioma are more responsive than neuroblastoma. Free Radic Biol Med 1999 May; 26(910): 1166-71.

14. Rogers MA, Simon DG. A preliminary study of dietary aluminium intake and risk of Alzheimer's disease. Age Ageing 1999 March; 28(2):2205-9.

15. Yokel RA, Allen DD, Meyer JJ. Studies of aluminum neurobehavioral toxicity in the intact mammal. Neurobiology 1994 December; 14(6):791-808. 